\title{
Me Bastard, You Bastard: Multiculturalism at Home and Abroad
}

JAPANKA AND OBA-CHAN

From Rovinj's post office to the old harbor it is some three hundred paces. You pass a half-dozen cafes. With a slight effort you can make it an even dozen. A shot of Istra Bitter here, a Pelinkovac there, Malvazija, Malvasia, before you know it, it's time for dinner. Yasuko does not take that route, I know. Two boys are chasing each other across the small slab of concrete behind the news kiosk. As she passes, they glance up and, without ceasing to run after each other in circles that now encompass her, begin calling, "Japanka, japanka!"

The road curves around the ancient movie house, now locked up, the words Kino and Cine fading on the crumbling facade, a heavy Habsburg rectangle, fifteen feet from the water. On file at City Hall are numerous ambitious and unrealized plans to resurrect it. Its solid stone appearance, like most old houses here, is belied by the bricks showing where the plaster has worn away. This is the only point of land visible between the old harbor and the new, where Austrians, Italians, Germans, and Croats from Zagreb keep their yachts for infrequent weekend sails. Before the 1991 war, many Serbs from Belgrade had yachts here, too.

I catch sight of her as she rounds the corner, with the unfortunate floating pizzeria to her left. She must see the old harbor in full view now, a semi-circle of dappled one-, two-, and three-storied structures set thirty feet back, enough space for hundreds of small tables and thousands of chairs, a narrow paved road, and a wide walk beside the water. The huge stones are worn smooth, slick. There is no barrier. Walk to the edge and you may fall in, though more likely you'll hit one of the tiny boats that, tied together and stacked three and four deep, cover the first fifty feet of the water's surface except during the early morning fishing hours. Until a few years ago, Ligio Zanini kept a boat here. Every morning he would collect his nets, exchanging a word or two of rovignese with his compatriots, and set out down the coast between Saint Catherine's and Red Island, named for the old brickworks. Thanks to his collection of 
poems, Conversations with Philip the Seagull, more than one gull in town is known popularly as "Philip."

The buildings sweep upward from right to left, where, at the summit of a hill, Saint Euphemia looks out on three sides. Her statue stands, guiding lost sailors, atop the fifteenth century bell tower, whose wooden steps one may climb, though the journey is not for the fainthearted. Yasuko takes a seat on one of the benches facing the water and the cathedral, the walled patio of a fish restaurant just behind her. In summer, it will be filled with tourists, but now it is locked and dark. No one will bother her here, she knows. I watch her from the other side and recall a similar stone street in old Rijeka from two weeks before, she and I strolling toward three teenage boys who stood in an arc facing the pedestrian traffic. One commented, snickering, with a glance at us and poked one of his friends with the toe of his shoe. I prepared to pass them by without comment, forcing my feelings into a compact ball at the base of my throat, but Yasuko had already released her hand from mine and was moving closer to him. "Do you speak English?" she asked. "Yes," he said, straightening, a little proud that he could have this conversation. "You're such a bumpkin," she said and turned abruptly away.

No, Rovinj's inhabitants are too discrete, or perhaps too shy, to point her out. They are used to tourists, outsiders, albeit not ones who look like her and not in the off-season. Even the little boys calling out japanka, who stopped and ran in another direction after a dozen or so paces, seemed to take only partial notice of her and were willing to incorporate her foreignness into their game without changing its rules. Their circle simply expanded. She places the camera on her lap and stares across the placid water at the old hotel, the clock tower, the central square with its fountain-a boy tipping a barrel-but does not see me standing under the arch that leads to the old center and St. Euphemia's.

The curve of the ancient town at the base of the hill, with the port authority, Veli Jože, and Valentino cafe on the exterior, only hints at the honeycomb of cale inside, the narrow stone alleys that pass for streets in all the coastal towns once controlled by Venice. Some thirty years ago, their basements were cleared of livestock, the streets repaired, plumbing installed; then small artisan shops appeared, and by the mid-nineteen seventies, Rovinj had become an artist 
colony, where droves of Belgrade intellectuals congregated every summer to relax, write, and debate the pursuit of culture in this idyllic setting. Most of the Serb-owned houses have fallen into disrepair, their owners not having shown their faces for many years. In some cases, Bosnian refugees have broken in and settled. The official policy of the Croatian government is that these are private homes and the refugees are breaking the law. But ask the town's inhabitants and you find that the law, at least for the present, is not enforced.

Just beyond is the theater "Gandusio" and beside it the farmer's market, always Yasuko's last stop before returning home. The leaf oba-chan waits for her there. The other women vendors know that Yasuko is her customer. When she came home late one morning, during the merenda, and told me of their first encounter, of her conversation with the woman she immediately took to calling, affectionately, half in English, half in Japanese, the "leaf lady," I was relieved. Discretion is very nice, but a little friendly nosiness now and again is sometimes not altogether unwelcome. Like the other vendors, the leaf oba-chan speaks no English. She is from Pazin, though she has lived in Rovinj for eighteen years-Yasuko's numbers have improved immensely through her daily marketing. Obachan's two children are grown. Yasuko is about their age. Oba-chan always stuffs something extra into Yasuko's bag, a handful of soup spices, an extra bunch of arugula, a leek. I imagine them communicating, all hands and facial expressions, Yasuko's numbers and assorted words in English, Croatian, Italian, and perhaps, once in a while, for color, German. The other women are envious of Oba-chan.

\section{Notes for an Ethnography I}

1. A Baster is a member of a racially mixed group of frontier people living in Namibia and northwestern South Africa. The name appears to come from the Afrikans word baster, meaning "half-breed." They were once also called Bastaards. They are believed to be descendants of eighteenth-century Dutch and French fathers and Khoi-Khoi (Hottentot) mothers. They speak a dialect of Dutch but have some knowledge of Khoi-Khoi. They long lived in autonomous hybrid communities founded in the nineteenth century, which blended various traditions and practices of their parent cultures. The early Basters were proud of their White ancestry, which they often emphasized to justify their claims of superiority over their aboriginal neighbors. 
2. Rovinj (pronounced "roveen," like a Russian saying "rowing" except without " $k$ " on end). Locals give it end stress, probably from Italian influence "Rovigno." Standard Zagreb pronunciation puts stress on first syllable. Pop. approx. 12,0oo. Perhaps this is false figure, at least overly generous. No young people to speak of. Seventeen appears to be the cut off. All depart for cities, Zagreb, Trieste, Padova. Even worse in surrounding countryside. Only when they come home does the town come to life. Butcher's shop fills, families strolling, people in line waving 200 kuna bills. Nothing like it otherwise. Depression. Drinking.

3. Old town breathtaking from every angle. We have tried all. You want to paint, snap photo after photo. Stopped at Valentino cafe for a drink before it closed for six months in off season. German waitress. Blah blah blah. Won't go back even when it reopens.

4. Living on outskirts of old town, five-minute walk from very center. Old, prob. about 1400 years. They say Rubinum or Rubinium was Roman town, but have found no evidence to support the contention. Narrow central streets, more like alleys, paved with big stone slabs. Slippery when wet. Dog shit. Must watch where going. Dogs don't.

5. Center narrow, mushroom-shaped peninsula with cathedral on hilltop, maze of alleys surrounding. Filled with art galleries and tourists in summer. Rest of the year a quiet fishing village. Insular. They celebrate end of tourist season every year, not beginning - very telling. We sat at a cafe during festivities, watched goat being slow roasted like at Greek Easter. Glowing coals reflected in harbor water.

6. "Bastard toadflax" refers to any of several small annual or perennial herbs of the sandalwood family that have narrow leaves like those of true toadflax. Other analogous uses include "bastard saffron," "bastard pimpernel," "bastard balm," in all of which cases sense appears to be "inauthentic" or perhaps "impure."

7. South of town long wooded area. "Punta Corrente." Yasuko wanted to swim, came out looking happy, child-like, then fell bad on rocks. I raced down to her, heart in throat. Terrible things happen when you're giddy.

\section{ONE PERSON'S STVAR-ANOTHER'S COSA}

Yasuko has made one other friend on her own. She talked about Milana for weeks before I had the opportunity of meeting her. She too is a transplant to Rovinj, having moved here six years ago to join 
her Dalmatian husband, Mladan, who runs one of the town's two electric shops. He is an HDZ supporter. HDZ, "HahDehZeh," Hrvatska Demokratska Zajednica, The Croatian Democratic Union, the nationalist party of Franjo Tudjman, in power from Croatian independence in 1991 until the 2000 elections and staunchly opposed to the concept of Istrianity, Istrianism, that hotch potch meld of Croatian-ness and Italian-ness and Slovene-ness and locality that yields a unique regional identity, distinct-some would have itfrom the centers of official nations. Mixture, hybrid, métissage, these and other cultural studies metaphors would seem to apply. For ten years the Istrian Democratic Party thumbed its nose at what it considered Tudjman's nationalist rhetoric. In response they provided new funds for Italian community organizations, changed street signs, developed bilingual slogans like "Naš put con la nostra gente""Our way" (in Croatian) "with our people" (in Italian). In reality, this is a rather tame example of the kinds of popular Istrianisms one encounters in daily use, expressions like "Napravimo džir"-_Let's take" (in Croatian) "a walk" (from the Italian, "giro") and "pagare la uplatnica"-"pay a" (in Italian) "bill" (in Croatian) and, a local favorite, "Je rivala kurjera?-Je rivala i partila," which means, "Has the bus come yet? It's come and gone," but which is made up of a consummate blend of Italian roots, Croatian endings, and regional, "čakavski" phraseology.

The most complete and compelling vision of a mixed Istrian identity has been furnished by the author Fulvio Tomizza, who, in works such as his Istrian Trilogy and especially, The Better Life, portrays characters who are naturally, unavoidably, of multiple ethnicities and cultures at one and the same time. It is not an uncontested vision. In an open letter to Tomizza printed in the Zagreb weekly Globus, in October of 1991, Nedjeljko Fabrio, president of the Croatian Writers' Union and himself an author of some repute, rearticulated an opinion originally expressed in his 1977 book, A Compilation of Lines, where he wrote: "The literature of Fulvio Tomizza is founded on the literary utopian idea that Istria ... is a distinct geo-ethnic and historical whole and that the inhabitant of Istria... is of mixed nationality, a bastard!" To the concept of a mixed culture, which Fabrio identified as a bastardization of one or another group, he responded in turn with a vision of Istria as "a ground of autochthonous valuesCroatian, Slovenian, and Italian." In effect, in place of a single hybrid 
culture Fabrio proposed a mosaic of cultures, each, in the philosopher Mikhail Epstein's formulation "completed and perfect."

On her way home, passing the Albanian bakery and Toni's restaurant, Yasuko meets one of the girls from next door, a Bosnian refugee named Snežana, who says hi in English. Yasuko smiles and says hi back. When Snežana's two friends say nothing, she smacks one of them in the shoulder with her palm and says, "Haj-te!" which to Yasuko's ears sounds like a version of "Go on!" but is actually Snežana's neologism meaning, "Say hi!" The two other girls say hi. Yasuko skirts the edge of Marshal Tito Square and buys two Kremsschnitzel from the Macedonian pastry shop on Via Carrera. The short, round Macedonian proprietress, the "Makedonka" as Yasuko has now taken to calling her, longs passionately to exchange even the smallest bit of greasy gossip about the town's, and especially Via Carrera's, inhabitants, about her no good Albanian neighbors, Dino's failed business ventures, that stupid Bošnjak who hangs out in their shop every afternoon and pesters the German girls in summer. Luckily for Yasuko, numbers are just not enough.

\section{Notes for an Ethnography II}

8. The Oxford English Dictionary lists a number of distinctive applications. A bastard is a kind of cloth, a variety of cannon, a big sail used in Mediterranean when there is little wind, a kind of war vessel, a type of sugar. What the OED does not say is that all these "bastard" entities are derived from two or more basic types of something. Mixtures, hybrids.

9. The English word "bastard" derives from the medieval Latin word bastum, meaning a pack saddle used by muleteers traveling inn to inn. Saying someone was a "fils de bast," or "son of the bastum," then, was a euphemistic manner of suggesting a child not born of the marriage bed. Probably related to word "bantling," corruption of German "bänkling," from bank, or bench, suggesting "child begotten on bench rather than marriage bed." These words originally carried a subtly allusive quality that contemporary usage of "bastard" makes seem ironic. There was a time in fact when bastard was a relatively common name. Its bearers include a minor French composer of the sixteenth century, a Devon family established at Kitley near Yealmpton in the late seventeenth century, a geographical district of Canada, Province of Ontario. With the term's subsequent descent into abuse, 
many former bearers of course changed their names, leaving most descendants ignorant of their true origins.

10. You can walk for miles down-coast. It zigs and zags through rocks, pine trees, covelets, park-like expanses of grass. A chigger-free fairy tale. Despite all, I imagine some might get crazy once in while. We've heard there is a higher than average suicide rate. "Rovinj sickness," they say. Haven't heard of real studies, only stories. Yasuko's friend Milana says it's because all the local landowners are inbred. A common story along the Mediterranean. Perhaps there's some kidding in this. Your village versus mine. I asked someone from the state hospital just north of town. He said Slovenia to the north has the highest suicide rate in Europe but as for Rovinj he was dismissive, called it a wive's tale. Strange we should come to such a place.

11. Depression for lack of activity, especially in the off-season, is understandable. Movies come one at a time, usually for two days. They won't actually show unless at least five tickets sell. One night there were only four of us. Arlington Road, I think it was. We waited until ten minutes after start time, hoping, but when nobody came, we bought the fifth ticket amongst us. At $\$ 2.75$ per, we felt we could have afforded all five. We didn't want to make others feel ashamed or poor or more envious than they might have already, especially since we must live here, and in a town this size seeing them again is highly likely. We are wealthy, lead the life of the wealthy, privileged. The movie was about people who believe news is real life and act on it. So where's the war here in "former Yugoslavia"?

12. Monday nights we take a yoga class through the local community college. Teacher is a Croat named Željko. Guru in India. Chainsmoker. The first couple of times I whispered what he said in Croatian to Yasuko, but soon there was no need (breathe in, breathe out, relax right side, relax left, close eyes, say "om," etc.).

13. "Flat bastard" is a type of metal file specific to North American system of pattern coarsenesses. Refers to tooth spacing or number of teeth per inch on file. "Bastard cut" has fewest number teeth per inch. More teeth, smoother finish after filing. More teeth, smoother finish. This usage analogous to "bastarda" script for less formal, vernacular texts in France and Germany during fourteenth, fifteenth centuries, "bastard" being synonymous with "less refined." More teeth smoother finish.

14. "Fat bastard"-British term for big wine. Unable to connect this to the hybrid notion, though it may be linked to the fact that big red wines are 
almost exclusively imported from France, in which case the bastard appellation would have other, more English, roots.

\section{THE MELTED POT}

"Gray is made of white and black," writes Nelida Milani-Kruljac in her memoir of life in Pula. "It isn't understandable from inside a tradition but stays at the horizon, beyond the sea.... Gray is the mist of a non-place, a mysterious entity that produces, bewilderingly, surprise, fear, curiosity, an invitation to 'walk far in someone else's shoes,' cutting capers, a freedom deprived of any oppressive sense of belonging." The gray of her own identity, claims Milani, is a freedom, an ability to change her national or ethnic color as the space around her is transformed. She is at one time Italian, at another Croatian, at still another Istrian, at others European, even if extra-communitarian. One can imagine that her self-characterization in this manner might appeal to any number of individuals concerned about maintaining, or more appropriately losing, their regional distinctiveness in an all-encompassing "Europe." Her cultural cameleonism, however, derives from an older problem, not from "Europeanization" but from a lifelong struggle at the border of multiple cultures.

Milani-Kruljac, a Zagreb-educated, retired professor of Italian in Pula, is editor of the Pula-Rijeka cultural review, "La Battana," and author of several books, including a nonfiction treatment of the phenomenon of diglossia in bilingual children and the award winning novella A Cardboard Suitcase (Una valigia di cartone, 1991). The memoirs from which I quote form half of an uneven, yet highly instructive exchange with Anna Maria Mori, a journalist from Rome, whose family emigrated from the region after World War II. Their collaborative 1998 book Bora is a work of reminiscences exchanged, therefore, from two vastly different standpoints, one the idealized nostalgia of West European emigration, the other a complex mixing of dream and self-analysis that can only be adequately characterized by the term "Yugoslav."

While Mori's aims become clear immediately-she is looking for herself in the past-Milani's motivations and concerns are complex. In her opening words, her first letter to Mori, she excuses herself for initially refusing (she hung up on her) to collaborate. It was, she writes, partly out of the fear of not being able to explain things too 
complexly intertwined with her own mixed idiom of Croatian and Italian. She asks, "Are you familiar with the death of unique things, the advent of doubled things?" But her hesitation also derives from a sense of estrangement from her "Italian brothers," from not recognizing herself in any of them. "We who remained had to adapt psychologically to the situation here, and traces of that adaptation can still be seen in each of us."

Each woman writes about adapting to and coping with the realities she has faced. Mori's experience of exile and new roots is reminiscent of the stories of North American immigrants, especially political refugees, Cubans, Russian Jews. Milani's far more profound prose is filled with anger and bitterness, nostalgia and philosophy. Both women have been professionally successful. But while Mori could hide her refugee heritage so long as to find proclaiming it at the end of their book a liberation of sorts, Milani describes coming to terms with her place over the years as an Italian in a "Slav" state, someone left behind in a sense, abandoned and transformed. Milani's living multiculturalism is, in the end, rather un-Italian. On the contrary, hers is a quintessentially Central European attitude, just as her prose, with its fact-based pathos, is often reminiscent of a writer like Danilo Kiš.

That there are individuals like Milani-Kruljac, who live in and articulate a single variegated Istrian culture, makes the position of a Fabrio (or a Tudjman for that matter) clearly untenable. Indeed, the utopianism Fabrio claims to find in Tomizza's vision is actually on the opposite side here. This is not surprising when one considers that the "mosaic of cultures" thesis, wherever it is applied in the world, always depends on a conception of perfect and unchanging cultural entities, rather like platonic categories (something is either A or not A) which neither borrow from nor affect one another. This abstraction has little to do with the natural categories of real life, where every meaningful exchange is based on consensual complicity, a recognition and acceptance of the middle ground on which every communicative act takes place. As an abstraction, "perfect culture" is created first in the human mind. From there it may find its way into the natural world, but like any transformation based on a preconception of how things ought to be, it must be worked at, sometimes violently.

This does not mean that the artistic depictions of Milani, and Tomizza before her, themselves reflect no rigidity. They too are, in a 
certain sense, idealized-partly by nostalgia, pathos, and the very conventions of writing. But they are rigid in yet another way. One that corresponds, I think, to a lack of fluidity in Istrian life itself, a cultural fixedness that distinguishes it from what is usually understood as multicultural in North American cultural debates. Yasuko first pointed this out to me. Her eyes were much better at seeing it than mine.

"Yes, Istria is heterogeneous, that's clear," she said. "You see it as soon as you cross the border, even before. But it's only heterogeneous with regard to what's here already, what's been here for a long time. In that way it is homogeneous. It's homogeneously heterogeneous." She searched for the right word. "It's a melted pot."

\section{Notes for an Ethnography III}

15. "Bastard" makes several appearances in the King James Bible. For instance, Deuteronomy 23:2: "A bastard shall not enter into the congregation of the Lord; even to his tenth generation shall he not enter in to the congregation of the Lord." Zechariah 9:6: "And a bastard shall dwell in Ashdod, and I will cut off the pride of the Philistines." Hebrews 12:8: "But if ye be without chastisement, whereof all are partakers, then are ye bastards, and not sons." But usage is inconsistent from one Bible translation to another. In several of the most recent translations, instead of "bastard," terms like "foreigner," "half-breed," as well as the phrase "born of a forbidden marriage" appear instead. The confusion seems to center around the Hebrew concept of the mamzer. According to rabbinic law, this refers to the offspring of individuals unable to contract a legal marriage, especially if it would be incestuous. The child of parents who are genealogically free to marry is never understood as a mamzer, so the term "bastard," whether in the sense of "mixed" or "illegitimate," does not apply. Such translations, it could be said, bastardize the mamzer.

17. Exploring the countryside while the weather's decent. Dalmatia last week. Our anniversary. Coast is beautiful, spectacular, more so even than California's. Tiny villages perched like birds' nests above the clear sparkle. Picturesque harbors. The highlight, call it that, was the drive through the inland areas, just inside the coastal mountains (the Velebit). Our landlady called this the best way to go because the roads are safer, less slick. I didn't think twice. Just the other side of the mountains, one, another, a third and fourth, and then like a great swarm of locusts, burnt out houses speckle the 
green. It dawns on me that this was the Krajina until recently, the sliver of Croatia that a half-million Serb inhabitants claimed as their own independent territory when Croatia declared its 1991 independence from Yugoslavia. We hadn't looked at a map, didn't know what towns the road passes through. It goes right down middle of the most devastated areas. Gospić, Gračac, Knin, the former Serb capital, where Ratko Mladic headquartered. Lush green countryside. Hundreds, thousands-we stopped counting-of burnt out, halfdemolished buildings, mostly houses, some clearly destroyed by fire, others with bullet and shrapnel holes along the sides. Here was war. News was real life. My only desire: to be completely away. No lights, empty darkness. Nothing.

18. Discovered a town on the coast we wouldn't mind coming back toMakarska, between Split and Dubrovnik. Rediscovered travarica, the herb brandy that's best in Dalmatia. Driving through Krajina made the rediscovery especially welcome.

19. French bâtard, or pain bâtard ("bastard loaf"), has now made its way into common English usage. The object it designates sits as if in smug mongrel defiance of the rows of pristine baguettes in boulangeries across North America.

2o. Arrived in Split late. Behind Diocletian's Palace, an old geezer laughing. Yasuko unnerved by his stare. Ask what problem is, he snickers. "Your kids," he says. What about them. Snickers. Walks away. Turns back. "Half-breeds." Walks further, turns. "Bastards." Just audible. Do not translate for Yasuko.

\section{ME BASTARD, YOU BASTARD}

Tall, slender, stylish Ines comes by in the afternoon and sets up in the middle of our living room floor, where Yasuko places a chair and sits down. Ines talks non-stop as she works, pushing hair forward, back, twisting it, wetting it, stepping back to consider. The gulls circling the tower of the Franciscan convent are visible behind her head through the open door, their cries mingling with the voices of the children in the yard. She looks back occasionally as though trying to discern one in particular. She apologizes for being late. Another argument with Mladan. She is Milana's friend but that Mladan, such a bigot. Doesn't understand a thing about Istria, even if he is a Dalmatian. It's a different world there. "Maybe it used to be like Istria," she says, "but it's not anymore. They've all forgotten." 
She likes to talk, but as her English is almost non-existent, she keeps turning to me for help. Each time I twist around from our tiny desk, she rests back on one heel, making circles with the scissors in the air and glancing from Yasuko's upturned face to mine and back as if she is afraid of losing the thread. Her grandfather was a Viennaeducated officer in the Austrian army. Her mother grew up in Buzet, her father in Galežana. They met on vacation in Poreč. One of her brothers went to school in Padova, the other in Belgrade.

Her kids ask her what they are. "What can I tell them? They're not Croats. They're not Italians. They're not Slovenes or Austrians or Serbs. Now they're not Yugoslavs." She parts Yasuko's hair and makes a small cut, letting the hair drop into her palm. "That used to help, you know. That made it easier. Being a Yugoslav. For me at least. Sometimes. It was an identity. You could go abroad. People in Italy or France or Germany knew what it meant." She smiles. "Okay. They thought they knew what it meant. You didn't have to explain is all."

There is a long pause in which the sounds of the gulls' cries and the children playing are augmented by the hint of sauteing garlic from our landlady's apartment below. Finally, Yasuko asks Ines whether she wishes Yugoslavia still existed. A roguish smile creases the edges of her lips and she shakes her head. "Oh, no. I'm no Yugonostalgic. Water under the bridge, you know? Just for my kids, that's all." She motions with her head through the door towards the voices below. "It's hard to know what to say to them when they ask. Everybody wants to be something, even if it's just something to rebel against. You know what I mean?"

I suggest to her that maybe she and her children are Istrians, but she crinkles her nose in disgust. Perhaps it seems too small, a regional identity for a region no one's ever heard of. If so, I can't help thinking she must be wrong, or else what am I doing here? "No, not Istrians," she says, shaking her head. She steps back, surveying her work, then cocks her head, listening, it seems, for the children's voices. "'You're the world.' That's what I say."

I turn and see Yasuko's full, pregnant face outlined in the bright light of the doorway. "That's nice," she says, smiling. "I like that."

"Yeah," says Ines, "that's what I say. There's nothing more important. Istria, Yugoslavia, whatever. I say, 'You're the world, the whole precious world.' What else is there?" 